\title{
Investigating the Image of Japanese Food on Intention of Behavior: Indonesian Intention to Visit Japan
}

\author{
Mega Mirasaputri Cahyanti ${ }^{1}$, Fatchur Rohman ${ }^{2}$, Dodi Irawanto ${ }^{2}$ \\ ${ }^{1}$ Master Program of Management, Faculty of Economy and Business, University of Brawijaya, Malang \\ ${ }^{2}$ Faculty of Economy and Business, University of Brawijaya, Malang
}

\begin{abstract}
Country-of-Origin Image (COI) has been recognized as a possible factor to influence the image of product especially toward international products. COI occurred due to the consumer's behavior which uses the nation image on some international products to consider the quality before they build a bearing on the products. The better the country's image in some products, the greater influence and impact will be given to their products image. Many previous studies have been done on $\mathrm{COI}$ toward foreign products, focused on the intention behavior. The intention behavior in this study is including a purchase intention or intention to try a product. However, research about its impact in the term of tourism is limited. Moreover, the use of international food as an object is limited as well. This study addressed an insight of tourism impact about Indonesian intention to visit Japan which influenced by image of Japanese food, which given by country's image (Japan). The results showed that the image of Japanese food perceived after they consumed it, significantly influence an intention to visit Japan. Therefore, marketing and promotions of a countries as one entity should focus to use their traditional food (international product for other people from other countries) to promote their country as tourism destination.
\end{abstract}

Keywords: Country of Origin Image (COI), Intention to Visit a Country, International food.

\section{INTRODUCTION}

Nowadays, the behavior of tourist are found more informed, mobile and adventurous than before. This phenomenon is important to be traced because it is not only a market for the future development of the tourist themselves but also the motivation to choose a country as a tourist destination. However, there are a lot of motivations behind the decision of the most tourist to visit a country. The attitude of many people such as like to try international product can be used as a prediction on their intention behavior [1]. For example, a recent study has been done by Phillips [2] which use country image of Korea and knowledge about Korean food, to build an intention to try the food and furthermore to visit South Korea. Therefore, the willingness on consuming international food can be used to predict their intention to visit a country.

The forming of consumer's intention to visit a country can occur due to the novelty seek. Novelty seek is one of the push factors or motivation that can be used as a precursor to increase the intention to visit a country. It can be described as follows; after a consumer have an experience in consuming international food,

\footnotetext{
* Correspondence address:

Mega Mirasaputri Cahyanti

Email :mega_mc@yahoo.co.id

Address : Permata Jingga, West Area C5
}

which is sushi and/or sashimi, they will feel curious to try sushi and/or sashimi in its original country. Therefore, to fulfill their curiosity aand to get a new experience, then visiting Japan is an action which may be taken. However, it still need a further research to confim this presumption.

International food such as Chinese, Japanese and Italian have shown significant popularity growth within the ethnic food market in Indonesia. The existence of the international food offers a unique concept of food, especially Japanese Food. Beside sushi and sashimi, Japan has many popular foods known by people in other country, e.g. tempura, nankotsu, tonkatsu, Chinese noodles, nuts, curry, yakiniku, cream puff, manju, dango, ochazuke, mochi, nigiri-zushi, udon, soba, donburi, okonomiyaki, takoyaki, and many more. However, based on Japan Guide [3], sushi and sashimi which use raw seafood such as fish, shellfish and shrimp as main ingredient, are the most well-known Japanese food. Therefore, sushi and sashimi were traditionally attached to the image of Japan which can provide a special experience on consuming it, both in Japan and in other countries. Image of sushi and/or sashimi as one of the well-known Japanese food, is healthy and fresh food [4] which contain omega 3 fatty acids, beneficial minerals and carbohydrates from the rice.

Only a few researches have been done on targeted food products [5] and exploring the country-of-origin image (COI) together with the 
international food and the intention to visit the country where the food is comes from [6]. Then this study aims to address the research need and provide meaningful information to international food marketers and developers for expanding their markets globally. We were investigating whether sushi and/or sashimi influences the intention of Indonesian to visit Japan after they consume it or not. It is appropriate when the researcher try to explore sushi and/or sashimi as an object to attract tourists to visit Japan.

\section{RESEARCH METHOD}

Questionnaire survey was developed to investigate the intention of Indonesian to visit Japan before and after consuming sushi and/or sashimi (Table 1). Most of the measurement items were adapted from previous studies: though/believed that sushi and/or sashimi is healthy; though/believed that sushi and/or sashimi is nutrious [7]; have plan to visit Japan soon [8]; Japan is safe and secure country to visit $[9,10]$. These fourth items include a statement about the image of Japan, Japanese food image and the level of consumer intention to visit japan.

Table 1.Items of Questionnaire

\begin{tabular}{|c|c|c|}
\hline No & Before & After \\
\hline 1 & $\begin{array}{l}\text { I thought that sushi } \\
\text { and/or sashimi is } \\
\text { healthy. }\end{array}$ & $\begin{array}{l}\text { I believed that sushi } \\
\text { and/or sashimi is } \\
\text { healthy. }\end{array}$ \\
\hline 2 & $\begin{array}{l}\text { I thought that sushi } \\
\text { and/or sashimi is } \\
\text { nutritious. }\end{array}$ & $\begin{array}{l}\text { I believed that sushi } \\
\text { and/or sashimi is } \\
\text { nutritious. }\end{array}$ \\
\hline 3 & $\begin{array}{l}\text { I have plan to visit } \\
\text { Japan in the near } \\
\text { future. }\end{array}$ & $\begin{array}{l}\text { I have plan to visit } \\
\text { Japan in the near } \\
\text { future. }\end{array}$ \\
\hline 4 & $\begin{array}{l}\text { Japan is safe and } \\
\text { secure country to visit. }\end{array}$ & $\begin{array}{l}\text { Japan is safe and } \\
\text { secure country to visit. }\end{array}$ \\
\hline
\end{tabular}

Respondents were asked about their level of agreement on each of the 4 statements about image of Japan and Japanese food on a 5-point Likert scale ( 1 = strongly disagree, $3=$ neutral, 5 = strongly agree). The survey also included respondents' demographic information such as gender, age, previous experience of consuming sushi and/or sashimi, and monthly income.

In this studies, the object was food product form Japan, i.e. sushi and sashimi. The concept in this study is aimed to develop a greater understanding about the overall study (Fig. 1). Based on previous study, an international food can be found as attractive things by consumer. Uniqueness was one of the reasons. Faced with a phenomenon above, consumers will have a curiosity not only to try those international food but also gathering various information related to the international food, such as where the food comes from.

International foods itself represent the image of the country origin. The image of a country origin will be automatically attached. Japanese people began eating sushi and sashimi in the $8^{\text {th }}$ century. The images of Japan is a sophisticated country in food producing that consider eating sushi and sashimi as protein sources. The habit of eating sushi and sashimi are believed to make Japanese people smarter.

To directly experience the international food and satisfy the curiosity of consumers, a visit to the country origin of an international food was a great choice for consumers. Thus, forming motivation to visit a country can be clearly explained step by step througout the evaluation of country of origin image attached in the international food. The dotted line in Figure 1 shown that consumer is potential to be a tourist after they tried the international food of a particular country. Researchers expected that these intention can be carried out by the consumer in the future. Therefore, intention in this study refers to consumer desire to visit Japan which may be performed in the future. In addition, a recent study showed that food is motivation for travel [11] and it is a key factor destination choice [12]. Therefore, some experts suggest that food is a good promotional tool for tourism destination [13].

\section{Sample and Data Collection}

The purpose of this study was to get a better understanding on Indonesian market and to assess the potency of Japan as tourism destination based on country image to build a future intentions. This study also considered a concept of country image which traditionally have been applied to the international products. We empirically investigated the application of these concepts to study potential consumers' intentions to visit the country of origin. The sample used for this study was consumer of three Japanese restaurants (Sugoi Tei, Saboten, and Hachi Hachi) in Malang, East Java which represent general Indonesian. Total of 300 questionnaires collected and processed. The demographic profile of respondents is shown in Table 2. This study employs convenience sampling of non-probability to consider the convenience and efficiency of the sampling. 


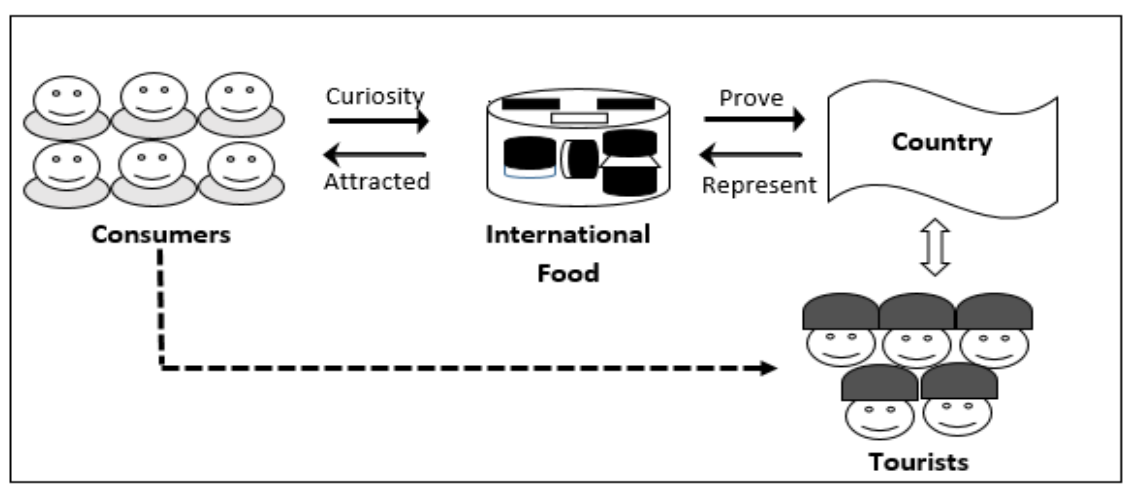

Figure 1. Concept of the Study

Table 2. Demographic profile of respondents $(n=300)$

\begin{tabular}{|c|c|c|}
\hline Demographic profile & $\mathbf{n}$ & $\%$ \\
\hline \multicolumn{3}{|l|}{ Gender } \\
\hline Male & 105 & 35 \\
\hline Female & 195 & 65 \\
\hline \multicolumn{3}{|l|}{ Age } \\
\hline $19-21$ & 51 & 17 \\
\hline $22-23$ & 46 & 15.3 \\
\hline $24-25$ & 203 & 67.7 \\
\hline More than 25 & 0 & 0 \\
\hline \multicolumn{3}{|c|}{$\begin{array}{l}\text { Previous experience consuming sushi } \\
\text { and/or sashimi on the last } 1 \text { year }\end{array}$} \\
\hline Never & 0 & 0 \\
\hline 1 times & 47 & 15.7 \\
\hline 2-5 times & 172 & 57.3 \\
\hline More than 5 times & 81 & 27 \\
\hline \multicolumn{3}{|l|}{ Monthly Income (Rupiah) } \\
\hline$<500,000$ & 22 & 7.3 \\
\hline $500,000-1,000,000$ & 66 & 22 \\
\hline $1,000,001-1,500,000$ & 45 & 15 \\
\hline $1,500,001-2,000,000$ & 31 & 10.3 \\
\hline$>2,000,000$ & 136 & 45.3 \\
\hline
\end{tabular}

From 300 respondents, 35\% were females and $65 \%$ were males. Over half of the respondent group $(67.7 \%)$ was under the age of $24-25$ and $17 \%$ is $19-21$ years or older. Half of the respondents had a previous experience consuming sushi and/or sashimi on the last one year around $2-5$ times (57.3\%) and $27 \%$ had more than 5 times consuming sushi and/or sashimi in the past one year. Almost a half (45.3\%) of the respondents were had a monthly income more than Rp. 2,000,000,- per month and $22 \%$ were around Rp. 500,000 - Rp. 1,000,000,-.

\section{Data Analysis}

Descriptive statistics were calculated by using the Statistical Package for the Social Sciences (SPSS v.20). T-test was used to analyze the data by involving two measurements on the same subject against a particular treatment effect. The first measurements were carried out before before consuming sushi and/or sashimi and the second measurement was done after consuming sushi and/or sashimi. Intention to visit Japan before they consume sushi or sashimi compared to the situation after they consume sushi or sashimi by using T-test.

\section{RESULTS}

Table 3 of T-test showed that there is an intention increasing on respondents to visit Japan, from a number average of 3.30 to 3.75 . It also show that there are more respondents who answered agree (4) after they consume sushi or sashimi compared to respondents who answered the statement before eating sushi or sashimi, with most disagree answer.

Table 3. T-test Results

\begin{tabular}{lcccc}
\hline $\begin{array}{c}\text { Consuming } \\
\text { Sushi or } \\
\text { Sashimi }\end{array}$ & Mean & $\mathbf{N}$ & Std. & $\begin{array}{c}\text { Std. } \\
\text { Error } \\
\text { Mean }\end{array}$ \\
\hline Before & 3.30 & 300 & .960 & .055 \\
After & 3.75 & 300 & .825 & .048 \\
\hline
\end{tabular}

Meanwhile, the Sig (2-tailed) comparison $(0.000)<\alpha(0.025)$, which implied that there is a significant effect of consuming Japanese food to the intention to visit Japan. The respondents' intention to visit Japan is increasing after consuming Japanese food (Table 4).

Table 4. Paired Samples Test

\begin{tabular}{|c|c|c|c|}
\hline \multirow[b]{2}{*}{ Variables } & \multicolumn{2}{|c|}{ Paired Differences } & \multirow[b]{2}{*}{$\begin{array}{l}\text { Sig. (2- } \\
\text { tailed) }\end{array}$} \\
\hline & $\begin{array}{c}\text { Std. } \\
\text { Deviation }\end{array}$ & $\begin{array}{l}\text { Std. } \\
\text { Error } \\
\text { Mean }\end{array}$ & \\
\hline \multicolumn{4}{|l|}{ Consuming } \\
\hline $\begin{array}{l}\text { Sushi or } \\
\text { Sashimi }\end{array}$ & 1.064 & .061 & .000 \\
\hline
\end{tabular}




\section{DISCUSSION}

This study considered two important concepts, country image and intention to visit a country which traditionally have been applied to the study of international food products. This study empirically investigated the application of these concepts to study potential consumers' intentions to visit the country of origin [14].

The study findings showed that Indonesian people's intention to visit Japan is influenced after they consume sushi and/or sashimi (Table 3). Therefore, we can assumed that the attitude on consuming sushi and sashimi gives a significant effect to Indonesian people's intention to visit Japan. Thus, this result also confirmed the idea about seeking novelty that underlies to form the intention to visit Japan using sushi and/or sashimi as a push factor motivation.

Japan government and private sectors need to educate the potential market segment about the country and food using various methods in order to promoting travel to Japan in the future. Japan might having Food Network specialists, which could focus on certain aspects of sushi or sashimi, including healthy and fresh characteristics as a promotional tool.

This result can give additional information to the marketing of Japanese Restaurant that constructing franchise from Japan, e.g. Katsusei, Hoka-hoka Bento, Sushi tei, Hanamasa and many more which exist in Indonesia. Those kinds of restaurant can be a strategic place to promote Japan as a tourism destination.

Since the increasing of respondents' intention to visit Japan after consuming sushi or sashimi was significant, then it can be conclude that sushi and sashimi can be used as an object to attract tourists to come to Japan. This result is also supported by the research of Phillips [2], which stated that individuals with a positive attitude on consuming international cuisine are more likely to form their intention to visit the original country of the international food.

\section{CONCLUSION}

We concluded that the use of international food of a country can be used as a media to attract consumers. Thus, it can be the right media to promote the origin country of an international food as a tourism destination country to visit along with the delivery of culture through the international food.

Most tourist may choose their tourism destination for many reasons. Food can be one of the reasons to choose the destination. It may not only food as their reason to visit, but at least they can end up remembering their travel on the food they experienced at the tourism destination.

\section{RECOMMENDATION}

The object of various international food and different country as a tourist destination could be used for a more representative and credible further research. Some other variables such as actual behavior may be included to investigate the possible effects of $\mathrm{COI}$ on consumer's actual behavior to visit a country origin.

\section{ACKNOWLEDGMENT}

The author would like to thank David Chang Ph.D, Prof. Vincent Li and Prof. Yevvon for the continuous support and review on the research.

\section{REFERENCES}

[1] Chen, H.L. 2009. Effects of country variables on young generation's attitude towards American products: a multi-attribute perspective. Journal of ConsumerMarketing 26 (3), 143-154.

[2] Phillips, W.J., A. Asperin, and K. Wolfe. 2013. Investigating the effect of Country Image and subjective knowledge onattitudes and behaviors: U.S. Upper Midwesterners' intentions to consume Korean Food and visit Korea. International Journal of Hospitality Management 32, 4958.

[3] Japan Guide. 2006. Sushi and Sashimi. http://www.japan-guide.com/e/e2044.html

[4] Yoshii, R. 2006. Sushi. Osaki, Tokyo: Tuttle Publishing, Yaekari Building.

[5] Skaggs, R., C. Falk, J. Almonte, and M. Cardenas. 1996. Product-country images and international food marketing: relationships and research needs. Journal of Agribusiness 12 (6), 593-600.

[6] Karim, S. and C. Chi. 2010. Culinary tourism as a destination attraction: an empirical examination of destinations' food image. Journal of Hospitality Marketing and Management 19 (6), 531- 555.

[7] Martin, I.M. and S. Eroglu. 1993. Measuring a multidimensional construct: country image. Journal of Business Research 28 (3), 191- 210.

[8] Ferns, B.H. and A. Walls. 2012. Enduring travel involvement, destination brand equity, and travelers' visit intention: A Structural Model Analysis. Journal of 
Destination Marketing and Management, 1 (1), 27- 35.

[9] Gallarza, M.G. 2002. Destination image: towards a conceptual framework. Annals of Tourism Research 29 (1), 56- 78.

[10] Lee, R., and L. Lockshin. 2011. Halo effects of tourists' destination image on domestic product perceptions. Australasian Marketing Journal 19 (1), 7- 13.

[11] Quan, S., and N. Wang. 2004. Towards a structural model of tourist experience: an illustration from food experiences in tourism. Journal of Tourism Management 25 (2), 297-305.

[12] Hu, Y. and J. Ritchie. 1993. Measuring tourism attractiveness: a contextual approach. Journal of Travel Research 32 (2), 25-34.

[13] Hjalger, A. and G. Richards. 2002. Research issues in tourism and gastronomy. In: Hjalager, M.A. and G. Richards (Eds.), Tourism and Gastronomy. London, England: Routledge, 36- 50.

[14] Lawrence, D., F. Fiegna, V. Behrends, J.G. Bundy, and A.B. Phillimore. 2012. Species interactions alter evolutionary responses to a novel environment. DOI: 10.1371/journal. pbio. 1001330 . 